\title{
Toplumsal ve Siyasal Bir Proje: Ansiklopedi ve Ansiklopedizm
}

\author{
Zakir Avșar $^{1}$ \\ Elif Emre Kaya² \\ Songül Omur ${ }^{3}$
}

\begin{abstract}
öz
Tarihsel oluşumu ve gelişimi açısından çok eski dönemlere uzanan ansiklopediyi yalnızca bütün bilgileri sistematik bir biçimde biraraya getiren bir başvuru kaynağı olarak değerlendirmek mümkün değildir. Özellikle 20. yüzyılın ortalarına doğru her ülkenin kendi ansiklopedisini oluşturmaya başlamasıyla birlikte diğer bilgi kaynakları gibi ansiklopediler de içinden çıktıkları toplumların gerek siyasi, ekonomik ve sosyal koşullarından etkilenmiş gerekse de siyasi, ekonomik ve sosyal oluşumlarını yansıtmaya başlamıştır. Bu anlamda bu çalışma, ansiklopedi kavramı ve ansiklopedinin ortaya çıkışını ve gelişimini ortaya koymaya çalışmakla birlikte ansiklopedinin toplumsal ve siyasal bir projeye dönüştürülerek, belirli bir döneme damgasını vuran ve diğer toplumları da etkileyen "ansiklopedizm"i incelemeyi konu edinmektedir. Betimleyici bir çalışma olan bu makalede mevcut literatür taranmış ve elde edilen veriler kronolojik bir sıralamaya konularak bir sonuca ulaşılmaya çalışıımıştır.
\end{abstract}

Anahtar Kelimeler: Ansiklopedi, Ansiklopedizm, Siyasal Oluşum, Toplumsal Oluşum.

\section{A Social and Political Project: Encyclopedia and Encyclopedism}

\begin{abstract}
Encyclopedia whose historical manifestation and development dates back to very old times cannot be solely regarded as a reference document which systematically brings all the information together. Especially with the start of every nation in materializing its own Encyclopedia towards the middle of 20th Century, encyclopedia has been influenced by the political, economical and social conditions of the its own society and has reflected the textures in these areas. In this context, this study aims to disclose the concept of Encyclopedia, its emergence, development and to examine Encyclopedism which has been transformed into a political and collective project that has influenced other societies as an icon of a certain area. In this article the current literature has been reviewed and presented in a chronological order which leads to the conclusion.
\end{abstract}

Keywords: Encyclopedia, Encyclopedism, Social formation, Political Formation.

1 Prof. Dr. Gazi Üniversitesi, Illetişim Fakültesi.

2 Dr. Gazi Üniversitesi Sosyal Bilimler Enstitüsü.

3 Arş. Gör. Gazi Üniversitesi, İletişim Fakültesi. 


\section{Giriș}

$\mathrm{T}$ arihi kökeni itibariyle M.Ö.384-322 yıllarına kadar dayanan ansiklopedi, dönemler boyunca gelişme göstererek varlığını sürdürmüş, değişik formatlarda, içeriklerde, temalarda zenginleşerek günümüze kadar mevcudiyetini korumuştur.

Ansiklopedinin ortaya çıkış sebep ve şartlarına, tarihsel gelişimine bakılması; aynı zamanda bilginin tarihsel gelişimine ışık tutulması, bilgi ve bilim tarihinin anlaşılması ve seyrinin kayıt altına alınması anlamına geleceği için, bu yönde yapılan çalışmalar önemlidir. Çünkü güç ve iktidar mücadelelerinde, bilgi hâkimiyetinin belirleyici etkenlerin başında olması, farklı formasyonlardaki bilgi toplayıcılıklarının incelenmesini gerekli hale getirmektedir. Bu nedenledir ki, nelerin bilgi olarak görülüp değerlendirildiği veya nelerin bilgi olarak görülmediği sorusunun cevabının aranması, keza bilginin etrafının çitlerle örülerek gettolar oluşturulmaya çalışılması ya da serbestleştirilip ulaşılabilir hale getirilip, adeta paketlenip sunulurken aynı zamanda "metalaştıııması" üzerine düşünmek, bilgiye atfedilen anlamların ardındaki güç iktidar ilişkilerini gözlemleyebilmek için gerekli ve faydalı bir uğraştır.

Bu çalışma, ansiklopedi kavramı ve ansiklopedinin ortaya çıkışını ve gelişimini ortaya koymaya çalıştığı kadar, ansiklopedinin toplumsal ve siyasal bir projeye dönüştürülerek, belirli bir döneme damgasını vuran öyle ki diğer toplumları da etkileyen ansiklopedizmi incelemeyi de konu edinmektedir.

Batıda ansiklopedinin ortaya çıkışını ve aydınlanma çağında geldiği noktayı irdelemek ve bunun Osmanlı toplumundaki izdüşümüne bakmak, bu topraklarda bilginin tarihini görmek ve aydınlanma projesinin bu coğrafyada nasıl algılandığını ve uygulandığını anlayabilmenin de yolunu açacaktır. Böylelikle ansiklopedinin toplumu çağdaşları ile aynı koşullara sahip kılmak için kullanılan bir eğitim aracı olmaktan, pazarlama tekniklerinin basit bir parçasına dönüşümünün izlerini ve nedenlerini sürebilmek mümkün hale gelecektir.

Betimleyici bir çalışma olan bu makale, aslında bir giriş niteliğindedir. Konuya ilişkin daha detaylı bilgilere ulaşıldığında esas üzerinde durulmak istenen güç-iktidar savaşlarında bilginin kullanımı ve ansiklopedinin bu anlamda toplumlardaki yeri konusu üzerinde daha detaylı durulacaktır. Dolayısıyla bu çalışmada mevcut literatür incelenmiş ve toplanan bilgiler paylaşılmıştır. Konuya ilişkin kaynakların kısıtlı olması, bilgiye erişimde bazı sıkıntılar yaratmakla beraber, mevcut bilgileri bir araya getirip bir literatür incelemesi yapılmış olmasının alana yine de önemli bir katkı sağlayacağı düşünülmektedir.

\section{Ansiklopedi Kavramı}

Ansiklopedi kavramına ilişkin çeşitli tanımlar bulunmaktadır. Bu tanımlardaki ortak ifadeler üzerinden gidilerek ansiklopediye ilişkin genel bir tanıma varmak ve bu yolla ansiklopediye ilişkin özellikleri belirlemek mümkündür. Ansiklopedi kavramına bakıldığında üç tanımlama biçiminde yoğunlaşma göze çarpmaktadır. Illkinde ansiklopedinin ya bütün bilim dallarını, ya da belirli bir bilim dalını kapsayan eser, başvuru kaynağı olma yönüne bir vurgu söz konusudur (Ana Britannica, 1993: 330; Dictionnaire Larousse, 1994: 159; Grand Master Genel Kültür Ansiklopedisi, 1992: 60; İnönü Ansiklopedisi, 1949: 88; Meydan Larousse, 1992: 553). Diğerlerinde ise, ansiklopedi kavramının kelime olarak kökeninden hareketle tanımlanmasına gidilmektedir. Buna göre, Yunanca kökenli bir sözcük olan ansiklopedi, Yunanca en (içinde), kyklios (çember) ve paideia (öğrenme) sözcüklerinin birleşmesinden oluşur ve "bütün bilim dallarını kapsayan öğretim ya da bir 
başka deyişle bütün bilimleri çevreleyen öğretim anlamına gelmektedir (Cumhuriyet Ansiklopedisi, tarih yok: 342; Genç Larousse, 1993: 284; Temel Britannica, 1992: 283-284). Üçüncüsünde ise, ansiklopedinin ele aldığı konuları sistematik ve alfabe dizinine uygun bir biçimde incelemesi yönüne ağırlık verilmektedir (Büyük Larousse, 1995: 661; Cumhuriyet Ansiklopedisi, tarih yok: 342; Gelişim Hachette, 1993: 222; Yeni Rehber Ansiklopedisi, ? : 197).

Bu tanımlamaların dışında ansiklopediye ilişkin farklı bilgilere de rastlanmıştır. Örneğin; Hegel'e göre ansiklopedi, bütünsel gelişimi ve kademeleşmiş bölümlerinin tümü olarak bilgi alanıdır (aktaran Büyük Larousse, 1995: 661). Bir başka görüşe göre de, ansiklopediler ve ansiklopedilerde kullanılan kategoriler, bir bilgi görüşünün, hatta bir dünya görüşünün (ne de olsa, ortaçağlardan itibaren dünya, çoğu kere de bir kitap olarak nitelendirilmiştir) anlatımları ya da cisimleşmeleri diye düşünebilir (Aktaran Burke, 2000: 94)4. Bir diğer kaynakta ansiklopedi, bilgilerin tümü, insan bilgisinin ansiklopedisi. Bütün insan bilimlerinin ilkelerini ve sonuçlarını ortaya koyan eser. Belirli bir bilim dalının veya bir bilgi serisinin bütün bölümlerini kapsayan eser olarak açıklanır (Meydan Larousse, 1992: 553) ve son olarak bir başka tanımda ise, Grekçede enkyklopaideia sözcüğünün, özgür bireyce öğrenilmesi gereken bilgi, davranış ve normları bir sistem içinde anlatan çalışma anlamına geldiği ifade edilmiştir (Oskay, 2008: 159). Bu noktada şunun da ifade edilmesinde yarar vardır ki, ansiklopedi tanımlarında geçen "bilgi"den, bilinmeye değer bilgi manasının anlaşılması gerektiği ve ansiklopediyi hazırlayanların önemli kabul ettiği konular hakkında kesin bilgi vermesi beklendiği belirtilmiştir (Yeni Rehber Ansiklopedisi, ? : 197).

Kaynaklarda, ansiklopediler, kapsadıkları bilgi ve hazırlandıkları yöntem açısından genel ve özel olmak üzere ikiye ayrılmaktadırlar: Genel Ansiklopediler, her konuda bilgi vermeyi amaç edinen eserlerdir. Özel ansiklopediler, bir bilim alanında ya da birbirine yakın konularda bilgi veren dar kapsamlı ürünlerdir (Alfabetik Okul Ansiklopedisi, 1990: 505).

Ansiklopediler düzenlenip hazırlanma yönünden ise ikiye ayrılmaktadır. Alfabetik, abece düzenine göre hazırlanan ki, çoğunlukla genel ansiklopedilerde bu yöntem uygulanmaktadır. Sistematik, konuya göre düzenlenen ve her konuyu bölümlere ayırıp inceleyen, özel bir çalışma biçimidir. Öte yandan kısa ansiklopedi maddeleriyle içeriği genişletilerek, bir sözlük niteliğine dönüştürülen ansiklopedik sözlük diye anılan ya da aylık dergi olmasına karşın ansiklopedi gibi düzenlendiği için aylık ansiklopedi adıyla bilinen başka türleri de vardır (Alfabetik Okul Ansiklopedisi, 1990: 505; Genç Larousse, 1993: 284).

Bu noktada ansiklopedilerde kullanılan alfabetik düzene ilişkin bazı eleştiriler yöneltildiğini hatırlamakta fayda vardır. Bu bilgilerde görülen şudur ki, 17. yüzyılın sonuna doğru gelindiğinde alfabetik düzenleme hala alışılmadık bir şeydir, öyle ki o dönemde çıkan bir eserde, bu yöntemin "sanıldığı kadar karışıklık yaratmadığı"nı ileri sürerek özür dilemek dahi gerekli görülmüştür. Yine bir başka çalışmada da alfabetik düzeni içe sindirememekten dolayı bir yakınma söz konusudur. Abece düzenine ilişkin en ciddi eleştiri ise "bilimi alfabetik sıraya sokulmuş teknik terimler aracılığıyla iletme çabalarının çılgınlığı" şeklindeki ifadedir (aktaran Burke, 2001: 186). Bilginin geleneksel tematik, organik ya da bütünsel düzenlenişinin büyük ve besbelli üstünlükleri olduğuna işaret eden Burke, alfabetik düzenin "keyfiliğinin" üstesinden gelinmek için başka maddelere çapraz göndermeler yapıldığını fakat bu göndermelerinde yıkıcı amaçlara erişebildiğini, "Eucharist" (Kuddas /Aşa-i Rabbani- ekmek /şarap ayini ) maddesinin sonunda "bkz. Yamyamlar" denilmesini de bu duruma bir örnek teşkil ettiğini ifade etmektedir (2001: 186-187).

4 Dolayısıyla, Ortaçağ ansiklopedilerinin erken Yeniçağda da kullanılmaya devam etmesi, hatta bazen yeniden basılması, hiç kuşkusuz, anlamlıdır (Burke, 2001: 94). 
Ansiklopedilerin sözlüklerden farkına gelince; ansiklopediler, sözcük ve deyimlerin yalnızca tanımını vermekle yetinmeyip, her konuyu belirli bir ayrıntı düzeyinde açıklamaktadırlar. Ansiklopedilerin öteki eğitsel metinlerden farkı ise kolayca başvurmaya olanak vermesi ve uzman olmayan okur tarafından da izlenebilmesi ve geniş kapsamlı oluşudur (Ana Britannica, 1993: 330).

Ansiklopedileri yapısal olarak incelediğimizde, bu eserlerin birkaç ya da çok sayıda ciltten oluştuğu ve genellikle de sonunda dizin yer aldığı görülmektedir. Ansiklopedilerde yer alan dizinler; okuyucunun aradığı bilgilerin, hangi maddelerde olduklarını gösterir (Temel Britannica, 1992: 283- 284), böylelikle araştırmacıların çalışmasına kolaylık sağlar.

Ansiklopedilerde yer alan bilgilerin güncelliğini koruması için; bilgilerin belli aralıklarla gözden geçirilerek yeni basımlarının yapılması ya da ek ciltler çıkarılması gerekmektedir (Temel Britannica, 1992: 283- 284). Bu husus, ansiklopedinin gözettiği belirtilen amaçlar arasında da sayılmaktadır, şöyle ki, ansiklopediler belirli bir disiplinle ya da disiplin grubuyla ilgili güncel bilgileri kapsamak, bu bilgileri bir sistem bütünlüğü içinde sunmak ve bilgiye en kolay biçimde ulaşılmasını sağlamak şeklinde üç amaç gözettiği belirtilir. Fakat bu üç amacın tek bir yapıtta uyumlaştırılabildiğine ender rastlandığı ve çoğu zaman bu amaçlardan bazı ödünler vermek zorunlu olduğunun altı çizilmiştir (Ana Britannica, 1993: 330). Belirtilen bu hususu ansiklopediye ilişkin önemli bir eleştiri saymak yerinde olacaktır.

Ansiklopedilerde olası eksiklikler bununla sınırlı tutulmamaktadır, örneğin her ne kadar, "XX. yy.da dünyanın çeşitli ülkelerinde yayımlanan ansiklopedilerin çoğunda, verilen bilgiler zamanın akışı içinde değişiklikler geçirdiği için siyasal bir tavır takınmaktan kişisel yorumlara gitmekten özellikle kaçınıldığı" görüşü yer alsa dahi (Gelişim Hachette, 1993: 224), "çok değişik konular hakkında oldukça geniş ve olaylara dayanan bilgiler içeren ansiklopedilerin, mümkün olduğu kadar tarafsız hazırlanmaları beklenirse de, ister istemez hazırlayanların fikir ve kanaatlerinin içeriklerinde belli olduğu ve bu insanlık zaafından kurtulabilenin olmadığı" yönündeki görüşler de mevcuttur (Yeni Rehber Ansiklopedisi, ? : 197).

Ansiklopedilerin "kişisel zaafların" taşıyıcısı olmalarına ilişkin duyulan hassasiyet, bu eserlere verilen değerin üzerinden biçimlenmektedir. Ansiklopediye ansiklopedinin tarihine bilim yaşamının gelişme sürecinin bir yansıması olması nedeniyle önem verildiği, yüzyıllar boyunca ansiklopedilerin, yayımladıkları tarihte var olan bilgileri kâğıda döken birer temel belge işlevi gördükleri söylenmiş̧ir (Ana Britannica, "Ansiklopedi Maddesi”, 1993: 330).

Bir toplumda ansiklopedinin varlığının "bir demokrasi kültürünün mevcudiyetine" işaret ettiği düşünülmektedir. Ansiklopedilerin insanların hayata kendi adlarına ve toplu bir görünüm içinde bakabilmek ve anlam verebilmek hakkını elde edebildiği toplumlarda ortaya çıkan bir tür olduğu ve üretkenliğini artırmaktan siyasal elit tarafından ve tefecilik niteliğindeki ekonomik etkinlikleri elinde tutan varlıklı kesimler tarafından bilinçli olarak alıkonulan Doğulu toplumlarda ise ansiklopediler görülmediği öne sürülmektedir (Oskay, 2008: 163). Bu yönüyle ansiklopedi basit bir "başvuru" kaynağı olmaktan çıkmakta, toplumların siyasal, sosyal ve ekonomik yapılanmasına ilişkin bir veriye dönüşmektedir.

Şu da belirtilmektedir ki, ansiklopedinin bir ülkede varlığının illaki onun Batıdaki emsallerine uygun bir zihniyetle tasarlanmış bir eser olduğunu da göstermemektedir, öyle ki, ansiklopedinin "bilgilenme ya da bilgilenme olanağına sahip olma, toplumsal hayatta bir statü simgesi" şeklinde bir göndergesi olduğu için bazı toplumlarda yer bulsa dahi, gerçek değerini üretemediği, "içinde 
oturulan ya da müdürlük, genel müdürlük, bakanlık yapılan iç mekânların tefrişindeki gibi, ciltler, cilt kapakları, ciltlerin renkleri, cici bici eşyaları "demirbaşa kaydedip" ona buna vermemek, alışkanlıkları gibi ansiklopediler de "öldürülerek" hayata katılıkları ifade edilmektedir (Oskay, 2008: 164). Daha açık bir deyişle, ansiklopedi de diğer bazı kavramlar da olduğu gibi, ithal edilmekte, ithal edilirken de temsil ettiği zihniyeti beraberinde getirmeyip, yalnızca şekli olarak yani göstermelik bir biçimde boy göstermektedir. Çünkü şunu anlıyoruz ki, ansiklopedi, "kendi adına hayata bütünlüklü ve özgün bir bakış içinde anlam verme" bilincine sahip olabilme ön koşulunu içinde barındırmaktadır (Oskay, 2008: 164).

Ansiklopedinin doğduğu topraklardaki serüvenine bakmak bu noktada daha anlamlı gelmektedir. Geldiğimiz noktada şunu anlıyoruz ki, ansiklopediyi salt bütün bilgileri sistematik bir biçimde içinde toplayan bir başvuru eseri olarak görmek oldukça sığ bir düşünce olacaktır, tarihsel serüvenini ve sürecini keşfetmek böylelikle içinden çıkıp geldiği zihniyeti anlamak ve yorumlamak ve böylelikle yeni bir noktaya ansiklopedizme ulaşmak ansiklopedinin bahsi geçen değerini layık olduğu yere oturtmak için daha anlamlı bir çaba olacaktır.

\section{Batı'da Ansiklopedinin Ortaya Çıııșı}

Ansiklopedinin Yunan medeniyetinin bir ürünü olduğu konusunda hem fikir olunmakla birlikte, "ilk ansiklopedik" ürünün hangisi olduğuna dair bir fikir birliği sağlanamamıştır. Bir kaynakta ansiklopedinin oluşturulma amacını da ortaya koyar bir biçimde, insanlığın çağlar boyunca oluşmuş ortak bilgisini herkesin ve sonraki kuşakların yararlanabileceği biçimde toplama düşüncesinin Milat'tan önceki yüzyıllarda doğduğu ve ilk ansiklopedinin M.Ö.384-322 yılları arasında yaşamış olan Aristoteles tarafından hazırlanmıştır bilgisi yer almaktadır (Genç Larousse, 1993: 284). Bir diğer kaynakta da, bazı kısımları bulunan en eski ansiklopedinin Grek düşünürü Platon'un yeğeni Speussippus'un ansiklopedisi olduğu ve bu ansiklopedide Platon'un doğa tarihine, matematiğe, felsefeye ilişkin görüşleriyle, Aristoteles'in Lycleum'daki aynı konularda yaptığı konuşmalara yer verildiği belirtilmekte ve ansiklopedilerin oluşturulma niyetleri şu sözlerle ortaya konulmaktadır: "Grekler ansiklopedilerinde, sözsel bilgilenim ortamlarında yapılmış tartışma ve konuşmaları kayda geçirme eğiliminde. Amaçları, bireyin hayata ilişkin olarak kendisi adına bilgilenmesi. Bilgilenme sayesinde, doğru düşünme yeteneğini geliştirmesi, canlı tutabilmesi. Böylece, özgür bireylerden oluşmuş bir site yaşamının gerçekleştirilmesi” (Oskay, 2008: 159).

Yine bir başka kaynakta, Martianus Capella'nın V. yüzyılda hazırladığı ve gramer, diyalektik, retorik, geometri, astroloji, aritmetik ve müzik olmak üzere yedi konuyu kapsayan kitabının Batı'da ansiklopedi denebilecek yapıtların ilki olarak kabul edildiği belirtilirken (Hilav, 2000: 12), bir diğerinde ise, "Yunanlıların anladığı anlamda ansiklopediye" örnek olarak Latin yazarı Terentius Varron'un (M.Ö.116-127) yazmış olduğu Disciplinarum Libri gösterilmektedir (Cumhuriyet Ansiklopedisi, ?, 342) ${ }^{5}$.

Bilimlerin gelişip çeşitli dallara ayrımasının ansiklopedinin kapsamını da genişlettiğini ve bu anlamda bilinen "ilk ansiklopedinin" ise Gaius Plinius Secundus'un (I.S. 23-29) 20.000 maddeyi ve Yunanlı, Romalı yazarlardan derlenen bilgileri içeren Historia Naturalis (Doğa Tarihi) adı 37 ciltlik Latin eseri olduğu bilgisi aktarılmıştır (Alfabetik Okul Ansiklopedisi, 1990: 505).

Ansiklopedilere ilişkin bilgileri toparlamaya devam ettiğimizde, kaynakların bizi Ortaçağ dönemine

5 Yunanlıların ansiklopedi olarak kabul ettikleri çalışmaların ne olduğu kavramını açmak gerekirse, Eski Yunanistan'da ve Roma'da yarı aydın bir kişi sayılabilmek ve bir meslek dalında tutunmak için kişilerin bir takım genel bilgilere sahip olması gerektiği” bilgisi verilmiştir (Alfabetik Okul Ansiklopedisi, 1990: 505). 
yönlendirdiği görülmektedir. Bu dönemde bütün bilgileri bir araya toplayan bir kitap meydana getirebilmek için zaman zaman çalışmalar yapıldığı ve bu çalışmaların bazen düzenli sayılabilecek bir yol izlediğini fakat genellikle yöntemsiz bir şekilde geliştirildiği belirtilmiştir (Cumhuriyet Ansiklopedisi, ?: 342). Buna karşın aynı dönemde bir tek bilim alanının ya da birkaç bilgi dalının tüm maddelerini kapsar biçimde hazırlanan özel ansiklopedilerin de yeterince olduğu söylenmiştir. Fakat öbür yandan, ortaçağ ansiklopedilerinin, özellikle Avrupa'da Rönesans döneminde bile bir din baskısı altında oldukları için içerdikleri bilimsel maddeler hayli yarar sağlayıcı olmakla birlikte, gözlem ve deneyime dayalı kaynaklardan çok Hıristiyanlık etkisindeki geleneksel kaynaklara dayalı olduklarından bugünkü anlamda ansiklopediler olmadıklarının da altı çizilmiştir (Alfabetik Okul Ansiklopedisi, 1990: 505- 506). Bir başka görüşe göre de, Ortaçağ boyunca çeşitli yazılar ve ilginç bilgiler içeren çok sayıda kitap yazıldıysa da, yazıların alfabetik bir düzen içinde hazırlanması 17. yüzyıldan önce gerçekleşememiştir (Temel Britannica, 1992: 284).

Ortaçağ dönemine ilişkin zikredilen "en eski ansiklopedilerinden biri" olarak "Speculum Majus" geçmektedir. Bu ansiklopedinin adının "Büyük Ayna" anlamına geldiği ve ansiklopedi adının da işaret ettiği gibi, "dünyanın ne olduğunu ve ne olması gerektiğini” birlikte anlattığı bilgisi verilmektedir. Yine aynı kaynakta, Ortaçağ'ın son zamanlarında İtalyan hümanisti Domenico Bandini tarafından 15. yüzyılda yazılan "Fons Memorabilium (Evren'in Kayda Değer Gerçekleri) başlıklı ansiklopedisinden söz edilmektedir. Buna göre bu ansiklopedi ile okumuş kişilere, derinlemesine ve çok geniş bilgi demeti sunulmak istendiğini ve ortaçağdan çıkışta bilgilenmenin, antikitede Platon'un dediği gibi "doğru düşünebilmenin ön koşulu" sayıldığı ve "hakikati aramak" görevinin, yeterince bilgi edinme "cehtine" katlanabilmiş ve birey olarak düşünme yeteneği kazanabilmiş kişiye düşen bir iş sayılmaya başlandığı ifade edilmiştir (Oskay, 2008: 160- 161).

Çağdaş ansiklopedi anlayışına doğru gidişte karşımıza ilk olarak, 1532'de Rabelais'in yayınladığı Pantagruelde ansiklopedi sözcüğünün "bugünkü anlamda" ilk kez kullanıldığı ardından da Hollandalı Ringleberg ile Hırvat Skaliç'in kullandıkları ansiklopedi deyiminin esasen Francis Bacon tarafından geliştirildiği bilgisi çıkmaktadır. Bununla beraber, alfabe dizinine uygun ilk ansiklopedi ise, İtalyan Marco Coronelli'nin 1701 yılında tamamını yayınlamayı başaramadığı eseri kabul edilmektedir (Cumhuriyet Ansiklopedisi, tarih yok, 342). Peter Burke, ansiklopedilerde alfabetik düzenin uygulanmasının Ortaçağ'da da örneklerinin görülebileceğini, fakat yeni olanın, bu bilgi düzenleme yönteminin bir alt- sınıflandırma yöntemi olmak yerine öne çıkarılması olduğuna dikkat çeker ve alfabetik düzene ilişkin şu saptamayı yapar: "Günümüzde bu sistem bize her ne kadar apaçık, hatta "doğal" görünse de, en azından başlangıçta yeni bilginin sisteme sindirilemeyecek ya da yöntemleştirilemeyecek kadar hızla geldiği bir sırada düşünsel entropi (bir sistemin kendiliğinden değişebilme yeteneği) güçlerinin kapıldığı bir yenilgi duygusundan kaynaklandığı anlaşılıyor (2001: 110).

Zamanla ilim ve sanat ilerledikçe, ansiklopedilerdeki "bilgi dairesi"nin de aynı ölçüde genişlediği belirtilmiş ve klasik ansiklopedinin en parlak örneğinin, F. Bacon'un ilimleri toplu olarak gözden geçiren ve sınıflayan Novum Orgaum (1620) adlı formel ve felsefi ansiklopedisi üzerine kavrayış ve metot bakımından kurulmuş olan ünlü Fransız Encyclopédie'sinde verildiği ifade edilmiştir (İnönü Ansiklopedisi, 1949: 88). Yine Moreiri'nin Büyük Tarih Sözlüğü (1674) ve Bayle'ın Tarihsel ve Eleştirel Sözlük'ü, hem içerik, hem de abece düzeniyle hazırlanmış olmaları bakımından modern anlamda ansiklopedinin ilk örneklerinden görülmekte, bununla birlikte Diderot ve d'Alembert'in yararlandığı Chambers'ın Cyclopaedia'sının bir "ansiklopedi” çalışması olduğunun daha kesin söylenebileceği belirtilmiştir (Hilav, 2000: 12).

Ephraim Chambers'ın çalışmasının ansiklopedi tarihinde önemli bir yeri muhakkaktır, çünkü 
Chambers'ın 1728'de Londra'da yayımladığı Cyclopaedia or an Universal Dictionary of Arts and Sciences'ın büyük ilgi görmesi sonucunda "ansiklopedi" terimi bu türün genel adı olarak benimsendiği söylenmektedir. Bu alana katkısı olan diğer bir isim de Michel de Ramsay'dır. Ramsay'in de 1737 yılında, bütün sanatları ve yararlı bilimleri derleyecek evrensel nitelikli bir yapıtın hazırlanması gerektiği görüşünü ortaya attığı ifade edilmektedir (Gelişim Hachette, 1993: 224).

Bütün bu gelişmeler aslında Ortaçağ'ın yerini aydınlanma çağına terk edişe bıraktığı değişim günlerine denk düşmektedir ${ }^{6}$. Bütün bu gelişmelerin doğal olarak "ansiklopedi” anlayışı üzerinde de etkisi olmuştur ve şu sözlerle ortaya konmuştur: "Düşünce alanındaki özgürleşme, doğanın doğrudan doğruya gözlemlenmesini isteyen deneyci felsefenin ve deneysel yöntemin gelişmesi, bilim ve teknikteki ilerlemeler, yeni bir ansiklopedi kavramının oluşmasına katkıda bulundu. Gerçekten, ansiklopedinin artık bilgilerin dökümünü ve eleştirisini yapmakla yetinmeyip, bilgisizliğe ve anlamsız inançlara karşı koyarak insan düşüncesinin gelişmesini de sağlaması gerektiği anlayışı yaygınlaşmaktaydı" (Gelişim Hachette, 1993: 224).

Peter Burke, erken Yeniçağ'da, özellikle 18. yüzyılda bu tür kitapların (başvuru kitaplarının) başdöndürücü bir çeşitliliğinin ortaya çıktığını ve grubun en belirgin üyelerinin de ansiklopediler, sözlükler, atlaslar ve bibliyografyalar olduğunu, 1500 'de ender olan sözlüklerin, 17. ve 18. yüzyıllarda çoğaldığını ve Avrupa dilleri dışındaki bazı dilleri de kapsamaya başladığını ifade etmiştir (2001: 170). Bu noktada "basım endüstrisinin" gelişimini gözden kaçırmamak gerekmektedir, çünkü Burke'un de ifade ettiği üzere, basım endüstrisinin ortaya çıkması, bu alanda iki önemli sonuç doğurmuştur; illki ansiklopedilere daha kolay ve daha geniş ölçüde erişilebilmesini sağlamıştır, ikincisi de ansiklopedileri basımcılığın icadından önce olduğundan daha gerekli hale getirmiştir (2001: 108).

İlkin yayınlanan ansiklopedilerin sayılarının ve hacimlerinin artıı̆ı, bu nedenle de daha ağır ve daha pahalı hale geldikleri ve bu hızlı gelişmenin bütünleyici karşııı olan "taşınır" başvuru kitabı için bir gereksinme yarattığı belirtilmektedir. Portatif kitapların basımı, "bunların yardımı olmadan gazete okunamayacağı, hatta doğru dürüst konuşulamayacağı" (Konversationslexicon fikri oradan gelmektedir) mantığını da yerleştirmeye çalışması açısından önem arz etmektedir (Burke, 2001: 172).

XVIII. yüzyıla doğru ansiklopedi çalışmalarının kişilerin çaba sınırlarını aşarak, bilim adamlarının ve düşünürlerin ortak eseri halinde yürütülmesine önem verildiği söylenmiştir (Genç Larousse, 1993: 284). Yeniçağ dönemine damgasını vuran ise, Diderot ile d'Alembert'in Fransa'da 28 ciltlik "Encyclopédie ou Dictionnaire faisonne des sciences, des arts et des metiers"i (Akılcı Bilimler, Sanatlar ve Meslekler Ansiklopedisi ya da Sözlüğü) olmuştur (1750-1777). Rousseau, Voltaire, Montesquie gibi zamanın dev düşünürlerinin yazılarını da içeren bu eserin, uygar dünyada olağanüstü bir ilgiyle karşılandığı ifade edilmiştir (Alfabetik Okul Ansiklopedisi, 1990: 506). Öyle ki bu eser, devrim önceki Fransa'da yatay işbölümü niteliğindeki gelişmelerin sonunda elde edilen bilimsel, ekonomik, siyasal ve kültürel düzey sayesinde, bilimsel buluşlara ve yenilikçi fikirlere öncelik veren ünlü ansiklopedi olarak tanımlanmaktadır (Oskay, 2008: 161-162).

Diderot ve d'Alembert'in ansiklopedisinin kendinden önceki aynı tür eserlerden hem biçim, hem de

6 Her ne kadar Ortaçağ ve Rönesans ansiklopedicilik anlayışında önemli bir farklılık bulunmasına karşılık, iki dönem için bir ortaklılığın mevcudiyetinden de söz edilmekten geri durulmamıştır. Buna göre, hem Ortaçağ, hem Rönesans ansiklopedileri "bir şeye bakmak için değil”, "okunmak için tasarlanmışlardı" (Burke, 2001 186187). 
içerik bakımından nitel olarak ayrıldığı belirtilmiş ve ansiklopedinin biçimsel özellikleri şu şekilde sıralanmıştır: “... kendisinden önce pek az örneği olan abece düzenine göre gerçekleştirilmesini, hacmi bakımından Zedler'in altmış sekiz ciltlik Universal Lexicon'u (1732-1750) dışında kendinden önceki bütün ansiklopedilerden daha büyük olmasını, iki yüzden fazla yazın adamı ve bilginin katkısıyla hazırlanmasını sayabiliriz. Aynı kaynakta ansiklopedinin içeriksel farkı ise, "bilgilerin, insanoğlu ve bu dünya için olduğu ve insanı sadece onların erdemli ve mutlu kılacağı düşüncesinin ileri sürülmesi ve geleneksel, dinsel, metafizik bilgi anlayışlarına karşıt bir tutumun benimsenmesi” olarak belirtilmiştir (Hilav, 2000: 12).

Diderot ve d'alembert'in ansiklopedisi kadar ilgi görmemekle beraber, o dönem içerisinde ismi geçen bir diğer ansiklopedi ise, yayımcı Panckoucke'un bir grup düşünüre hazırlattığ $1^{7}$ ve 1781 'de çıkan eserdir (Genç Larousse, 1993: 284). Yine aynı dönemde günümüzde de oldukça bilinen Encyclopaedia Britannica ansiklopedisi karşımıza çıkmaktadır. Britannica, ilk kez 1768'de İskoçya'da haftalık fasiküller biçiminde yayımlanmış olup, 1771'de tamamlandığında 2.689

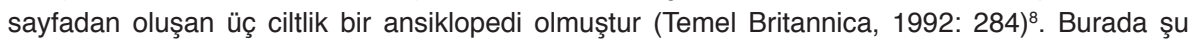
görüşün altının çizilmesi gerekir ki, "çok ciltli ansiklopediler bilginin ticarileşmesini özel bir açıklıkla örneklendirirler, çünkü büyük çaplı girişimler için eşdeğer büyüklükte sermaye yatıımı gerekir” (Burke, 2001: 172-173).

Özetle, yakınçağın başlangıcında salt bilimsel eserler olarak ele alınan ve bu anlayış doğrultusunda hazırlanan ansiklopediler, 19. yüzyıl ortalarında bilginin artık halka da yayılması ve mal edilmesi görüşünden yola çıkarak, niteliklerini yavaş da olsa değiştirmeye başlamışlardır. Genel ansiklopedilerle, uzmanlık ansiklopedileri birbirinden ayrılmış ve bu tarihten başlayarak da günümüze kadar gelen genel ansiklopediler önemli ölçüde yaygınlaşmıştır (Alfabetik Okul Ansiklopedisi, 1990: 506; İnönü Ansiklopedisi, 1949: 88).

20. yüzyılda Fransa'da Larousse Yayınevi başta olmak üzere dünyanın birçok ülkesinde ansiklopedi yayımlama geleneği sürdürülmüştür. Son zamanlarda ansiklopediler renkli resimleri, çarpıcı baskıları, güzel görünümlü cilt kapaklarıyla evlerin salonlarını süslediler. Öte yandan The Bridgeplayer's Encyclopaedi (Briç Oyuncusunun Ansiklopedisi) 1980, gibi içerdikleri konuları günlük yaşamın en hafif düzeyine indiren türleri de yaygınlaşmıştır. Ayrıca ansiklopediyle terimler sözlüğü arası nitelikte olan ve "sözlük" adı altında yayımlanan tek ciltlik cep kitapları da giderek çoğalmıştır; İngiltere'de Penguin Yayınevi'nin ansiklopedik cep kitapları bilgiyi daha ucuza ve daha kısa boyutlar içinde satmaya yönelik çalışmalara örnektir (Alfabetik Okul Ansiklopedisi, 1990: 506). XX. yüzyılda ise, hemen her ülke, hiç değilse yarı resmi bir nitelik taşıyan, ulusal bir ansiklopediye kavuşmuştur (Cumhuriyet Ansiklopedisi,?: 343).

7 Peter Burke'un kitabında, Pancoucke'a ilişkin şu bilgiler yer almaktadır.: “... bilgi ticaretinin 18. yüzyılda yeni bir şey olmadığını göstermiştir. Yeni olan bilginin büyük bir işletme haline gelmesiydi. Encyclopédie'nin yayıncılarından Charles Joseph Pancoucke'un ansiklopediyi bir para işi diye nitelendirmesi bunu özetlemektedir. On yedi dergiye sahip olan Pancoucke bilgiyi satma sürecini başka pek çok kişiden daha iyi biliyordu (aktaran Burke, 2001: 173-174).

8 Britannica'na ilişkin olarak şu bilgiler paylaşıımıştır: "En modern ansiklopedi olan ve faydalı olmayı amaç tutan bu eserin metodu, bilgi alemindeki büyük malzemeyi elemek, bunun özünü, halkın anlayabileceği şekle sokmak, fazla bilgi edinmek isteyenleri de maddelere eklenen bibliyografyalar araciyle uzmanlık eserlerine sevk etmektir. Bir ansiklopedinin kapsadığı bilginin \%75’i uzun müddet olduğu gibi kalabildiği , \%25'sini ise konuya göre 1,2,3 yıl içinde değiştirmek gerektiği için, bu ansiklopedi eskiden 3-14 yıl arayla yeni basım yaptığı halde, 24 cildini birden 1942'den beri her yıl takım halinde tazelemektedir" (İönü Ansiklopedisi, Ansiklopedi Maddesi, 1949: 89). 


\section{Osmanlı İmparatorluğu’nda ve Türkiye'de Ansiklopedinin Ortaya Çıkıșı}

Osmanlı İmparatorluğu'nda ansiklopedinin ortaya çıkış sürecine bakmadan evvel, Batılı toplumlar haricinde ansiklopedinin ne şekilde geliştiğine kısaca bakmakta fayda vardır. Örneğin Çin'de bilinen en eski ansiklopedinin I..̈.220'de hazırlanan Huang-lan (İmparatorun Aynası) adlı çalışma olduğu belirtilmektedir (Oskay, 2008: 159-160). Çin'deki ansiklopedicilik anlayışının Batı ile kıyaslandığında farklılıklar gösterdiğine işaret edilmektedir. Buna göre Çin'de Avrupa'dakine benzer bir enformasyonun "metalaşması" yönünde bir eğilimin var olduğunu, fakat bunun ansiklopedilere kadar uzanmadığı ayrıca Çin'de Batı klasik geleneğinin tersine, kesintililik olmadığı, süreklilik arz ettiği belirtilmektedir. ${ }^{9}$ Yine aynı kaynakta, Ming döneminden (1368-1644) 139 ansiklopedi bilindiği, Çin ansiklopedilerinin Batıılıardan çok önce devasa hacimlere ulaştığı bilgisi yer almaktadır (Burke, 2001: 175). Bu dönemin sonrasında ise, 1725 yılında yayınlanan her cildi 80 sayfalık, 10.000 ciltten oluşan bir ansiklopedi kaynaklarda göze çarpmaktadır ${ }^{10}$. Bu çalışmaları ise, büyük ve ulusal nitelikteki ansiklopediler dönemi izlemiştir (Genç Larousse, 1993: 284).

İslam dünyasında ise Müslümanlar ansiklopedi karşıı̆ı̆nda Külliyat, Dairat-ül-mearif, Muhitül-mearif, Kamus, Mevdüa, Tabakat ve Mevsu'at gibi isimler kullanmışlardır (Yeni Rehber Ansiklopedisi, ?: 198). Burada konulara göre yazılmış olan ve ansiklopedi niteliği taşıyan yapıtların en ilginci, o dönemin hemen hemen bütün bilgilerini kapsayan ve "ihvan-ı Safa" diye adlandırılan bilginlerin X.yüzyılda hazırladıkları elli iki risaleden oluşan yapıt olduğu söylenmektedir (Hilav, 2000: 12). Bir başka kaynakta ise Farabi'nin X. ve İbni Sina'nın XI. yüzyılda Arapça olarak yayımladıkları eserler, çağdaş anlamda ilk ansiklopediler olarak kabul edilmiştir (Genç Larousse, 1993: 284).

Ansiklopedi sözcüğü Osmanlıca'ya Muhitü'l - maarif diye çevrilmiş; bilgilerin çeviren’i (çemberi) ya da çevrim'i anlamına geldiği belirtilmektedir. Taşköprülüzade'nin Mevzuatu'l-ulum'u (XVI.yy.) Katip Çelebi'nin Keşfü'z-zünun'u (XVII.yy.) Erzurumlu İbrahim Hakkı'nın “Marifetname”si (XVIII. yy.) ansiklopedik yapıtlar arasında sayılabileceği söylenmiştir. Yine Emrullah Efendi'nin 1900'de ancak bir cildini yayımlayabildiği Muhitü'l-maarif isimli bir ansiklopediden bahsedilmektedir (Hilav, 2000: 11-12) ${ }^{11}$. Türkçe ilk tam ansiklopedi ise, Şemsettin Sami'nin 1889'da çıkardığı 6 ciltlik Kamus-ül A'lam'dır (Özel İsimler Sözlüğü). Türk Tarih Encümeni'nce başlatılan ve Milli Eğitim Bakanlığı'nca tamamlanan İbnül Emin M. Kemal İnal'ın Son Asır Türk Şairleri (1930-1942), Türk harfleriyle basılan ilk ansiklopedik eserlerdir (Genç Larousse, "Ansiklopedi Maddesi”, 1993: 285).

Ansiklopedi sözcüğünün Türkçeye girişinin 1920'ler olduğu ifade edilmiştir, öyle ki, M. Bahaettin'in 1926'da basılan Yeni Türkçe Lügat'ında bu sözcüğe rastlanmaktadır ve bilgilerin, bilimlerin, sanatların, tekniklerin tümünü kapsayan yapıt anlamında kullanılmaktadır (Hilav, 2000: 1112). Cumhuriyet'ten sonra ilk genel ansiklopedi ise, Cumhuriyet gazetesinin çıkardığı 10 ciltlik

9 Bir diğer ayrım olarak ise, Çin ve Batı ansiklopedilerinin örgütlenmeleri, işlevleri ve okuyucuları arasındaki karşıtlık belirtilmekte ve Çin toplumunda basımcılığın daha çok denetlenen, zaman zaman kitap üretilmesi engellenen ve hatta satılması yasaklanan bir yapıya sahip olduğu ifade edilmektedir (aktaran Burke, 2001: 176).

10 Ünsal Oskay bu eserin yayın yılının 1720 olduğunu belirtir ve Çin'de yayınlanan ansiklopedilere ilişkin şu saptamayı yapmışıı: “...Çin ansiklopedileri, ne var ki Batı'dakilerden çok farklı olmuş, Amaçları, Grekler gibi "kendisi adına düşünebilecek, bilgili ve doğru düşünme yöntemine sahip insanlar yetiştirmek" değil. Devlet memuriyeti sınavlarına hazırlanacak olanlara klasik metinleri ve bunları yeniden ve yeniden yorumlayan değişik yüzyıllardan eski bilginlerin görüşlerini sunmak olmuş “(2008: 160).

11 İslam tarihinde ve Osmanlı Devleti'nde yapılan ansiklopedi çalışmalarının pek azının genel ansiklopedi niteliğinde olduğu belirtilmiştir (Yeni Rehber Ansiklopedisi, ?: 198). 
Hayat Ansiklopedisi'dir(1932-1936). Daha sonra Alaettin Gövsa 1933-1938 yılları arasında 4 ciltlik Meşhur Adamlar ansiklopedisini çıkarmıştır (Genç Larousse, 1993: 285). 1940'ta İslam Ansiklopedisi yayınlanmıştır. 1943'te İnönü Ansiklopedisi (1950'den sonra Türk Ansiklopedisi olarak yayınını tamamlamıştır). 1961'de Hayat Yayınlarının hazırladığı Hayat Ansiklopedisi 1968'de Arkın Kitabevinin çıkardığı Cumhuriyet Ansiklopedisi ilk genel ansiklopedilerdir. Son yıllarda ise, genel ve özel birçok ansiklopedi çıkarılmaktadır (Yeni Rehber Ansiklopedisi, tarih yok: 198).

\section{Ansiklopedizm}

18. yüzyıl, Batı'da Aydınlanma sürecinin başladığı dönemdir"12. Burada aydınlananın "insan aklı" olduğu ve bu durumun aklın inanca karşı yeni bir başkaldırısı olduğu belirtilir. Buna göre; "Batı düşüncesinin rasyonel düşünmeye verdiği aşırı önem, Aydınlanma akımı ile aklı aşan sınır durumlarıyla ilgili her şeye sırt çevirmekle yetinmeyip, XIX. yüzyılın pozitivist, scientist ve materyalist akımlarıyla birer postüla şeklinde olanları inkar etmeye kadar varacak ve modern zihniyetin gelişmesini sağlayacaktır” (Kafadar, 1997: 22-23). Ansiklopedizm ise ansiklopedi yazarlığı anlamına gelmekle birlikte; on yedinci ve on sekizinci yüzyıllardaki Aydınlanma Evresinde evrenin düşünsel ve bilimsel düzeyini tümü ile özetleme amacını güden Genel Ansiklopedia'nın kitabının ortaya getirilmesine önemli katkılarda bulunan Denis Diderot ve Jean d'Alembert'in yazı, görüş ve etkileri anlamında kullanılmaktadır (Karamanoğlu, 2007: 28-29) ${ }^{13}$.

Fransa'da Diderot'nun yönetimi altında yayımlanan 35 ciltlik bu büyük ansiklopedinin (17511772) Chambers'in bir yayınından (1729) esinlenilerek oluşturulduğu ${ }^{14}$ ve amacının bilimin ve düşüncenin her alanda kaydettiği ilerlemeleri tanıtmak olduğu ifade edilmiştir. Ansiklopedinin yazı kadrosunda Voltaire, Montesquieu, Rousseau ve Jaucourt gibi düşünürlerden başka, hekimlerin ve mühendislerin yer aldığı belirtilmiştir (Dictionnaire Larousse, 1994: 159).

Aydınlanma Çağı'nın önde gelen düşünürlerinden Denis Diderot, ansiklopedi sözcüğünü şu şekilde açıklamaktadır: "Bu sözcük, bilgilerin art arda gelişi ve bir araya getirilmesi anlamını taşır ve eski Yunanca "en" bağlacı ile daire ve bilgi anlamına gelen adların (kyklos ve paideia) birleştirilmesinden ortaya çıkmıştı". Diderot ansiklopedinin amacını ise şu sözlerle ortaya koymuştur:

“...yeryüzündeki bölük pörçük ve dağınık bilgileri biraraya getirmek, birlikte yaşadığımız insanlara, bu bilgilerin genel sistemini açıklamak ve bizden sonra gelecek insanlara aktarmaktır. Böylece daha önceki yüzyıllarda yapıımış çalışmalar, daha sonraki yüzyılların işine yarayacak ve daha bilgili hale gelmiş torunlarımız, hem daha erdemli ve hem de daha mutlu olacaklar ve biz de insan ırkına yakışır kişiler olarak ölüp gideceğiz" (2000: 127).

12 Peter Burke, Almanya'da 1450 yılı dolaylarında seyyar harflerle basımevinin icadından, 1750'de Encyclopedie'nin yayınlanmaya başlaması arasındaki yüzyılları erken yeniçağ olarak tanımlamaktadır. Ona göre, Encyclopedie zamanında var olan enformasyonun bir toplaması olduğu kadar, bilgi, siyaset ve iktisadının da canlı bir gösterimidir (2001: 11).

13 ... Bilimsel bilgi modern özellikleriyle Yeni Çağ'da ortaya çıkmıştır. Olgucu temellerini İngiliz ampirizminde, idealist temellerini Fransız ansiklopedistlerinde ve Saint Simon-Comte pozitivizminde bulan modern bilimin en önemli özellikleri evrensellik ve nesnellik iddiasıdır (Koyuncu, 2013: 7).

14 Bir başka kaynakta Diderot ve d'Alembert'in Encyclopédie'ye Chambers'in Cyclopaedia'sının Fransızca çevirisi olarak başladıkları ifade edilmiştir. Ansiklopedilerinden biri oldu. (Temel Britannica, "Ansiklopedi Maddesi", 1992: 284). 
Bu çalışmanın, Avrupa kültür yaşamında derin ve sürekli bir etkisi olduğu ifade edilmektedir. Bu anlayışa göre ansiklopedi sözcüğü insanın edindiği bilgilerin tümünü kapsamayı amaçlayan bir üründür. Ansiklopedik bilgi, özgün ve derin bir bilgi olmaktan çok, saygınlığı olan bütünleyici bir bilgidir; yani evrende var olan her şeyin bilgisini kendinde toplama amacını güder. Bu anlamda ansiklopedik bilgi; Hegel'in sözünü ettiği gibi "saltık bilgiye" karşıttır. Çünkü bu dünyayla ilgili bilgilerimiz sürekli değişmekte ve gelişmektedir (Alfabetik Okul Ansiklopedisi, 1990: 508; Görsel Büyük Genel Kültür Ansiklopedisi, 1987: 668).

Ansiklopediciler giriştikleri bu toplumsal projede; kabullenilmiş bütün inançları, bilgileri, değerleri, gelenekleri, toplumsal kurumları, böyle bir aklın süzgecinden geçirip eleştirmeye yönelmişlerdir. Öyle ki, Ansiklopedi'nin savunduğu bilgi anlayışı, metafizik sorunların doğal olarak bir yana bırakılması sonucunu vermiştir. Ansiklopedicilerin hemen hepsi; hoşgörüsüzlüğü, bağnazlığı, kurumsallaşmış dini ve dolayısıyla kurulu düzeni şiddetle eleştirmişlerdir. Bu düşünürlerin amacı, yaygın ve kalıplaşmış inançları aklın ışığında inceleyip geçersizliklerini göstermek ve insanoğluna eleştirel bilincini ve doğal özgürlüğünü kazandırmaktı (Hilav, 2000: 13-14). Ansiklopedizmin bu yönü dikkate alındığında Peter Burke'un bu projenin düşünsel bir proje olduğu kadar siyasi bir proje olduğu yönündeki vurgusu daha anlamlı hale gelmektedir (2001: 115).

Bu düşünceler doğrultusunda, devlet ve siyasal iktidar konusunda Ansiklopedicilere bakıldığında, genel olarak aydın ve bilgili bir hükümdar (aydın despot) yönetimini ya da meşruti monarşiyi savundukları, laiklikten yana oldukları, devletin, toplum yararına çalışıp, toplumun düzenini ve mutluluğunu sağlamalı; yurttaşların kişisel inançlarına ve düşüncelerine karışmamasını inandıkları, ekonomi alanında ise din ve siyaset felsefesindeki kadar eleştirici ve ileri olmadıklarını; genellikle özel mülkiyeti ve ekonomik liberalizmi savundukları ifade edilmektedir (Hilav, 2000: 14-15).

Ansiklopedicilerin büyük katkısıyla; akıl deney bilgisi ve eleştiri üzerinde temellenmiş bir yeni düşünce tarzının radikal bir biçimde ortaya konması ve savunulması, Devrim'den önce Fransız halkının yaşam koşulları ve siyasal iktidarın tutumuyla derinden ilişkili görülmüştür. Fransız maddeci düşünürleri ve Ansiklopedicilerin, devlet, Kilise ve kurulu düzen ile hak duygusunun ve aklın istemleri arasındaki çelişkiyi irdeleyip ortaya koydukları ve tepki gösterdikleri; insanların içinde bulundukları bu koşulların bilincine varmalarının ve özgürlüklerinin ellerinden alınamayacak bir şey olduğunu kavramalarının düşünsel olanaklarını yarattıkları ve böylece Fransız Devrimi'nin zeminini hazırladıklarına işaret edilmektedir (Hilav, 2000: 17) ${ }^{15}$. Ansiklopedistlerin Fransız Devrimi'nde "büyük rol" oynadığını Ünsal Oskay da teslim eder, fakat Oskay, Diderot ve arkadaşlarının ansiklopedilerinin kendilerinden önceki yüzyıllarda yazılmış ansiklopedilere göre daha elverişli sosyo-kültürel koşullarda yazıldığı için etkin olduğunun da altını çizmiştir (2008: 162).

Böylesi bir toplumsal ve siyasi bir proje haline dönüşen ansiklopedizm bazı yerleşik egemenlik ilişkilerine ilişkine ciddi eleştirileri gündeme getirip, itibar görmesi ile birlikte, "eleştiri" oklarının üzerine gelmesi ve engellenmelerin de oluşması kaçınılmaz hale gelmiştir. Öyle ki, devrinin dinsel dogmalarıyla çatışan bu tutumu nedeniyle hücumlara uğramış ve parlamento bir kararnameyle, ansiklopediye tanımış olduğu ayrıcalığı geri almıştır (Cumhuriyet Ansiklopedisi, ?, 343).

Fakat her dönem yasaklamaların beraberinde "ilgiyi" de getirmesi gerçeği burada da kendisini göstermiştir. Esere yönelik bütün eleştirilere ve uygulanan yaptırımlara karşın, eserin uyandırdığı

15 Aydınlanma Çağında Montequieu (1689-1755), Kanunların Ruhu'nda Locke'dan ilham alarak geliştirdiği "kuvvetler ayrılığı" görüşüyle, Ansiklopedistlerden önce Fransız İhtilalinin fikri atmosferini hazırlar (Kafadar, 1997: 23). 
ilgi (abone sayısı kısa bir süre içinde 1000'den 4000'e yükselmiştir), Le Breton ile Diderot'nun güttükleri usta politika ve devrin ileri gelenlerinden bazılarının bu yayını desteklemeleri, ansiklopedinin devamını sağlamıştır (Cumhuriyet Ansiklopedisi, ?, 343).

\section{Osmanli'da Ansiklopedizm}

Şerif Mardin, Osmanlı İmparatorluğu'nun Batı ile hiçbir zaman ilişkisini kesmediğini bununla beraber Yükselme Devrinde Osmanlıların kendi uygarlıklarını Batı'nınkinden üstün saydıkları için Batı'nın bir "model" olarak izlenmediğini buna karşın, imparatorluğun gerilemeye başlamasıyla, niçin gerilediği sorusunun, önce devlet yönetiminin bozulduğu ileri sürülerek, daha sonra belki de yüzeyleşen bir tutumla Batı'nın askeri üstünlüğü gösterilerek cevaplandırılığını ifade eder (2002: 9-10) ${ }^{16}$. Bir başka görüşe göre de toprak kayıpları neticesinde "Batılılaşma" düşüncesi ile karşı karşıya gelinmiştir ve Tanzimat'tan çok önce başladığı ifade edilen bu "cereyanda" birincil amaç, üstünlüğünden kuşku duyulmayan Batı dünyasının ulaşığı seviyenin fikri ve felsefi temellerini gözlemlemek ve öğrenmektir. Bu noktada Osmanlı'nın klasik alim profilinde görülen içe dönük, manevi yolculukların yerine; gözleme dayalı, dışa dönük bir bilgilenme süreci ikame edilmiştir (Uğurlu ve Balık, 2009: 2309).

Osmanlı aydınındaki değişimlerin izlerini takip ettiğimizde, bazı görüşlerin değişimin asıl başlangıcını Tanzimat süreci ile bağdaştırdıklarını ve bu sürecin de Doğu ve Batı toplumları kaynaklarının çevirisi ile geliştiği bilgisi ile karşılaşılmaktadır. Aynı kaynaklarda, Tanzimat aydınına ilişkin çizilen portrede aydınların ansiklopedisyen olma isteği içinde oldukları ve devlet adamından yazarına bu toplumun seçkinlerinin; tiyatrodan gazeteye, mimariden filolojiye ve doğa bilimlerine kadar her konuya el atma ve düzenleme çabasında oldukları vurgusu göze çarpmaktadır (aktaran Öztürk, 2001: 51). İlk roman yazarı olan Şemseddin Sami, ilk sözlükleri ve ansiklopediyi de ortaya koymuştur. Sadrazam Ali Paşa, Güllü Agop'un Osmanlı tiyatrosunu devletin finanse etmesini gerekli görmüş ve bazı temsilleri de teşvik için izlemiştir. Ahmet Vefik Paşa, tiyatro çevirmenliğinden sözlükçülüğe kadar her alan el atmıştır". Ancak bu eklektik ve aktarmacı tutum, kendisini daha çok tarih, iktisat ve sosyoloji alanlarında göstermiştir. Öyle ki, 19. yüzyılın sonunda referans kitaplığı ve derleme kütüphane kurumu fikir ve girişim olarak Osmanlı aydınları arasında yerleşmiştir (aktaran Genç, 2007: 145). Bu ansiklopedist ve eklektik anlayış, Tanzimat aydınıyla birlikte daha sonra genel geçer bir biçimde her dönemdeki Türk aydınlarına da sirayet etmiş ve onların bütünlüklü, uzun soluklu ve kendiliğinden doğan düşünümselliklerini sürekli bir biçimde baltalamıştır. Ancak onların bu yönelimi tesadüfi bir tercih de değildir. Zira tarihsel ve toplumsal koşullar sürekli bir biçimde Türk aydınının "toplumsal eyleme bağlı düşünce" içerisinde ontolojik temel bulmasına teşne olmuştur (Genç, 2007: 145).

Tanzimat aydınının "ansiklopedizm" akımı ile ilişkisini daha net bir biçimde görebilmek için dönemin aydının düşüncelerine daha yakından bakılmalıdır. İlk olarak şunun belirtilmesinde fayda vardır: Osmanlı aydını ilerlemenin temel belirleyeninin bilim olduğu kanaatine ulaşmış ve onu elde etmenin tek yolu olarak da pozitivizmi görmüştür (Uğurlu ve Balık, 2009: 2310) ${ }^{17}$. Yine 1880’li

16 Batı'ya ilişkin başlayan bu merak duygusu bazı çözümlere gidilmesine yol açmıştır, Örneğin, Yirmisekiz Mehmet Çelebi, Nişli Mehmet Ağa gibi devlet katında görevli kimseler Avrupa'nın "ahvali"ni öğrenmeye çeşitli başkentlere elçi olarak gönderilmişlerdir. Öte yandan Batı uygarlığının kişinin refahına yönelik değerleri Osmanlı idareci sınıfına sızmıştır (Lale Devri) (Mardin, 2002: 10). Avrupa'yla ilgili ilk sistematik değerlendirmeler, devamlı diplomatik ilişkilerin bir ürünü olarak Batı'da görevlendirilen Osmanlı hariciye memurlarından gelmiştir. Osmanlı İmparatorluğu için Batı'nın genel bir "model" olarak kullanılmasına dayanan "düzeltme"(tanzimat) teklifleri de buradan kaynaklanmıştır (Mardin, 2002: 11).

17 Bilimin fazlasıyla aşkıncı bir konuma oturtularak eskiden dine atfedilen rolün bilimle yer değiştirmesi neticesinde toplumun dini yaşam biçimiyle, yerine geçirilmek istenen bilim arasında bir çatışma ortamı 
yıllardan itibaren Osmanlı kültür hayatında pozitivizm ve benzeri maddeci disiplinlerin etkileriyle oluşan materyalizm görülmeye başlanmıştır (aktaran Uğurlu ve Balık, 2009: 2311). Özellikle materyalizm akımının Osmanlı aydının düşünsel hayatı üzerindeki etkisini anlamaya çalışmak ansiklopedizmin Osmanlı toplumundaki yerini görebilmek için önemli bir konu olarak karşımıza çıkmaktadır. Çünkü Osmanlı materyalizminin oluşumunda manevi yönü oluşturan dolaylı düşünsel kaynağın 18. yüzyıl Fransız ansiklopedistleri ve materyalistlerinin düşünceleri olduğu ifade edilmektedir. Bu görüşe göre, "(g)enelde Osmanlı aydınlarının, din ve gelenekten bağımsız, kendi kendine yeterli bir aklın gücüne değer vermeleri, 18. yüzyıl Fransız ansiklopedistlerinin etkisiyle olmuştur. Kökü Tanzimat'ın ilk yıllarına kadar uzanan bu etki pozitif bilimin oluşmasında laik içerikli kültürün yapıcı rolünü Osmanlı aydınlarına benimsetmiş ve dinsel sezginin 'tevekkül'e varan onaylatıcı tutumu yerine, aklın eleştirici özelliğini koymuştur. Geleneksel kurum ve düşünce biçimlerinin köklü bir eleştirisini başlatan bu anlayış, Osmanlı materyalizminin gerçeği kavrama anlayışı olarak salt akıl ve duyumları temel alma ilkesini belirlemiştir (aktaran Uğurlu ve Balık, 2009: 2312). Bu noktada materyalizmin geleneksel kurum ve düşünce biçimlerini sorgulanabilir bir anlayışı gündeme getirmesi, aydınlarında kendi aralarında bölünmelerine yol açmıştır. Daha açık bir ifadeyle, bilim - din karşıtlığı mı, bilim ile dinin uzlaştırılması mı o dönem aydınlarının kendilerini konumlandırmalarında cevaplamaları gereken bir problematik haline gelmiştir ${ }^{18}$.

Şerif Mardin de, ansiklopedist anlayışın tarihsel seyri ve etkisinden şu şekilde bahsetmiştir: “Ansiklopedizm'in temeli bilimin bir politikası olmadığı düşüncesiydi. 1860'ta bu görüşe katılanlara göre, "Batııılaşmak", insanın bilgisini artırmaktı. Sonradan Namık Kemal ve Yeni Osmanlıların edebi alana egemen olmalarıyla bu tutum değişti. Batııılaşmak, parlamenter rejim yanlısı olmak ve onu Osmanlı İmparatorluğu'nda yerleştirmek çabasıyla bir sayıldı. Buna Batıılışmanın "siyasileştirilmesi" diyebiliriz ve o devirden beri memleketimizde Batılılaşma teorilerinde bu iki ana tutumdan esinlenen, iki ana akım meydana geldiği söylenebilir. Ahmet Mithat Efendi bir ansiklopedistti, Jön Türkler'se, Batılılaşmayı yeniden bir siyasi sorun olarak ele almışlardı. Geniş çapta, Jön Türklerin Avrupa'da kaldıkları süre içinde geçirdikleri fikri gelişme birinci akımın bazı yönlerinin doğruluğuna kanaat getirmeleri, bir kültür politikasının zorunluluğunu keşfetmeleriyle ilgilidir. Burada özellikle "kültür politikası" deyimi üzerinde durmak gerekir. Jön Türklerin bir kısmı söz konusu ettiğimiz iki akımın bir sentezini meydana getirmeye çalıştıkları derecede her iki akımdan ayrılıyorlardı. Öte yandan bu yeni sentez, Jön Türklerin bazılarında, 19. yüzyılın sonunda ve 20. yüzyılın başında beliren "siyasi"nin "kültürel" kanadı altına alması eğiliminin tipik bir belirtisi olarak ortaya çıkıyordu. Abdullah Cevdet, (2012: 226) kültür sorunlarını çözümlemeden önce hiçbir şekilde politika yapılamayacağına inandığı derecede, daha çok, eski "ansiklopedist" akıma dönüşü temsil ediyordu.

doğmasına zemin hazırlamıştır (Uğurlu ve Balık, 2009: 2310).

18 Örneğin; Osmanlı materyalizmine katkısı kabul edilen Abdullah Cevdet mekanik bir şekilde; dinin tamamen anlamsızlaştığı ve yerini pozitif bilime terk ettiği tezini savunmaktan kaçınmıştır. Daha uzlaşımcı bir tavır sergileyen Abdullah Cevdet'in düşüncesinin özetini Şerif Mardin "halk"ı eğitmek, Osmanlı kütlelerini medeniyet akımına katmak isteği olarak ifade etmiştir (Mardin, 2012: 225). Oysa ansiklopedistlerin bazıları bilimi dinin yerine almakta ısrarlı olmuşlardır. Orhan Pamuk'un Sessiz Ev romanındaki ansiklopedist Selahattin Darvinoğlu da bunlardan biridir ve muhtemelen "din" konusundaki tutumu nedeniyle Abdullah Cevdet'i hedef alır . Örneğin; "Şu Apdullah Cevdet'e bak, son kitabı ne bayağı şey, hepsi Delaheye'den yürütülmüş, ama kendi düşüncesi gibi yazıyor, üstelik yalan yanlış, anlamadan. Hem, din ve sanayi konusunda, Bourguignon okunmadan artık bir şey söylemek mümkün değildir: O ve Ziya Bey hep başkalarından yürütüyorlar: Hem de anlamadan: Zaten Ziya'nın Fransızcası kıttır, okuduğunu anlayamaz, şunları bir yazı yazıp rezil edeyim dedim, ama kim anlayacak; hem böyle ufak tefek şeyler için kalemşorluk edip ansiklopedime vermem gereken vakitleri ziyan etmeye değer mi? (Pamuk, 1994: 92) Bir başka yerde de şunları belirtir: "Şu Abdullah Cevdet'in risalelerine bak, yüzeysel, basit herif, gerçeğin hepsi bu kadar mı yani, hem sonra De Passet'i yanlış anlamış Bonnesance'ı hiç okumamış üstelik fraternite kelimesini yanlış kullanıyor, ama bu heriflerin neresini düzelteceksin, hem zaten düzeltsen kim anlar, aptallar bu ahmak halka her şeyi basit anlatacaksın ki anlasınlar, zaten bu yüzden o bilimsel buluşları anlatayım diye imanım gevriyor yazılarımın orasına burasına atasözleri ve deyimler yerleştiriyorum ki anlasın hayvanlar! (Pamuk, 1994: 136). 
Aydınlanmanın, politik girişimler ve pedagojik girişimler olarak iki yöntemle gerçekleştirilmeye çalışıldığı görüşüne başka kaynaklarda da rastlanmaktadır. Bunlardan birinde, aydınlanmanın temel özelliklerinden birinin eğitim yolu ile kalkınmaya daha çok önem verilmesi olduğu ve bu işin önce ansiklopedizm ve okumaz yazmazlıkla mücadele biçiminde başladığını, ardından kurumlaşmaya gidildiği ifade edilmiştir. Ayrıca, Fransız Aydınlanmasında Helvetius, Diderot, Voltaire ve Rousseau'nun inandığı gibi, Türkiye'de Şinasi, Ali Suavi, Ziya Paşa, Namık Kemal, Ahmet Mithat Efendi, Hoca Tahsin gibi aydınların insanların hürleşmesinde ve toplumun kalkınmasında birinci rolü eğitime verdikleri ifade edilmiştir (Öztürk, 2001: 52).

Bu noktada şu ayrıma gidilebilir, toplumun kalkınması için eğitime önem verilmesi ve bunda da ansiklopedistlerin ve aydınlanmacıların etkisi genel kabule yakındır. Fakat ismi zikredilen aydınların konuya yaklaşımında bu eğilimleri yansıtırken, bunları ne şekilde algıladıkları ve yansıttıkları değişiktir. Şöyle ki, Şinasi'nin şairliğinin, yazarlı̆̆ının, tiyatroculuğunun, gazeteciliğinin her şeyden önce uygarlaşma yolunda çalışarak insanların yetiştirilmesine, halkın aydınlatılmasına yönelik olduğu belirtilmektedir. Araç ne olursa olsun amaç Şinasi için halkın eğitilmesidir. Ilerleme ve uygarlaşma halk eğitimi ile sağlanabilecektir. Bu bakımdan onda XVIII. yüzyıl Fransız Aydınlanmacı ve ansiklopedistlerinin etkisi açıktır. Ancak özel olarak şu veya bu düşünürün tek tek etkisinde kalmamış, "batıdan filan ve falan yazarın değil bir uygarlığın ve düşünce düzeninin dersini almıştır (aktaran Öztürk, 2001: 52). Şunu net olarak görüyoruz ki o dönem aydının ansiklopedistlerden ve aydınlamacılardan etkilenmesinin bir nevi kendi içinde "yaklaşım" farklılıkları vardır, kimisi Şinasi örneğinde olduğu gibi bunu bir "uygarlık ve düşünce biçimi" şeklinde içselleştirirken, kimilerinde ise bunun "eksik ve yüzeysel bir bilgi depolayıcılığına" dönüştürülmesi söz konusudur.

Öyle ki Şinasi ve diğer aydınlar üzerinden yapılan yorumlar da bizim bu yöndeki görüşümüzü destekler biçimdedir. Buna göre 1860 'larda Şinasi örneğindeki gibi, her şeye rağmen 'ilkeli' ve 'ideolojik' bir toplum kritiğine yöneldiği söylenebilecek bir aydın tutumunun yanında, aynı yıllarda ikinci bir akım oldukça farklı bir kültür birikimi yaratmıştır. Bu birikim 'eleştirel söylem'e çok daha az önem vermiş ve farklı bir Batıııaşma stratejisi izlemiştir. Mardin bu ikinci akıma 'ansiklopedizm' adını vermektedir. Ona göre, bu akım içerisinde yer alanların amacı, "çok fazla 'zülf-i yar'e dokunmadan Osmanlı İmparatorluğu'na 'faydalı' saydığı gelişmeleri yansıtmaktır" (aktaran Genç, 2007: 145). Bir başka deyişle, bu iki farklı eğilimin bir çatışması söz konusudur. Buna göre, 1860 'lardaki siyasallaşma eğiliminin bir yansıması gazetelerin birdenbire çoğaldığı, didaktik ve ansiklopedik olmaktan çok polemik ve politik yaklaşıma sahip yeni bir gazeteci aydın zümresinin ortaya çıkı̆̆ı belirtilmiş ve bu gazeteciler ile ansiklopedistler arasındaki ilk çatışmanın, Münif ile Refik Bey arasındaki kavgada somutlaştığı bilgisi verilmiştir (Korkmaz ve Bilici, 2011: 43).

Bu çatışmaya dair bir başka bilgi ise şu şekildedir: "Ilk ve ikinci kuşak Tanzimatçılara karşı sistematik eleştiriler ise 1860 'larda başladı. Namık Kemal ve Ziya Paşa önderliğindeki bu eleştiriciler grubuna "Yeni Osmanlılar" adı verilmiştir. Yeni Osmanlılar, Tanzimatçılar’ın sömürü olayını anlamadıklarını, bir "üst-tabaka" meydana getirdiklerini, kendi kültürlerini kösteklediklerini (şeriatı unuttuklarını) ve ancak yüzeysel anlamda "Batıı" olduklarını ileri sürdüler. Tanzimatçıların - Yeni Osmanlılar’a göre Batı'nın "ruhu"nu oluşturan hürriyetçi ve parlamenter eğilimleri anlamadıkları da yüzlerine vuruluyordu. Bu yıllarda Batı hakkındaki bilginin artması ve yayılması, Yeni Osmanlılar'ın önemli bir rol oynadıkları, Osmanlı gazeteciliği yoluyla olmuştur” (Mardin, 2002: 13-14).

Bu noktada, Mardin tarafından da "ansiklopedist" olarak nitelenen Ahmet Mithat'a yönelik düşünce ve yorumları gözden geçirdiğimizde, "ansiklopedizme" ilişkin yukarıdaki ifadelerle de örtüştüğünü düşündüğümüz bazı eleştirilerin izini sürmek mümkün hale gelmektedir. Fakat bunun öncesinde 
Ahmet Mithat'a ilişkin olarak "olumlu" denebilecek şu düşünceye yer verilmesinde fayda vardır. Buna göre, II. Abdülhamit devrinde, Batı'daki edebi tartışmaların Osmanlı imparatorluğuna yansımasının istenmediğini, hatta konan bu yasakların sonucunda ansiklopedizm denen akımın yeniden canlandığını ve bu türden en çok eser vermiş olan kişilerden birinin de gazeteci, romancı ve "ansiklopedist" Ahmet Midhat Efendi olduğu ve onun sayesinde Osmanlı okurunun Batı'daki edebi tartışmalardan, bilimin gelişmelerden, hatta Batı'daki din aleyhtarı cereyanlarından haberdar edildiği ifade edilmiştir (Aktaran Çetinkaya, 2008: 107). Buna karşın tam tersi yorumlar da söz konusudur:

“...Sosyal statü açısından dönemin edebi zirvelerine mukabil toplumun alt katmanlarından, bir atar çıraklığından gelmiş olan Ahmed Midhat Efendi, Midhat Paşa'nın himmetiyle bambaşka bir insan olmuş ve az da olsa (dönemimize kıyasla oldukça fazla) bir şeyler öğrenip Fransızca tahsil etmiştir. Hace-i Evvel unvanını alınca varlığının farkına varmış ve bir milletin Hace-i Evvel'i olmaya azmetmiştir. Eksik, sathi ve bazen de yanlış birçok şey öğrenmiştir. Fakat bu önemli değildir. Bunlar, birçok eksikliği olan topluma yeter de artardı bile. Ahmet Midhat'ın bu çok şeyi bilmesi, okuması ve öğrenmesi onu dönemin ansiklopedist yazarı yapmıştır (Yiğitbaş,1998: 124). Bu ifadelerde ilk göze çarpan şey, halkın bilgi açısından oldukça "eksik" görüldüğüne dair bir inanca sahip olunduğu ve bu "cahil”liğin giderilmesi için bilgi ayırt etmeksizin her türlüsünün "sorgulanmaksızın" kabul edildiği ve "çok şey bilmenin " ansiklopedist" olma anlamına geldiği vurgusudur.

Bir diğer kaynakta ve biraz da alaylı bir üslupla yazarın "ansiklopedizme" yönelişi şu şekilde anlatılmaktadır:

“...Geleneksel ülkülerin geride bırakılması ve onların yerini yeni ülkülerin almasını- örneğin eğitimin halka geniş bir şekilde yayılması fikrinin yerleşmesini- Ahmet Midhat Efendi'nin başından geçen ilginç bir olayla örneklendirebiliriz. 1869 yılında Bağdat'ta o zamanın valisi olan Midhat Paşa'nın emrinde çalışan Ahmet Mithat Efendi, Osmanlı Güzel Sanatlar Okulu'nun müstakbel kurucusu Osman Hamdi Bey ile tanıştı. Bir Osmanlı aydını olarak başarısıyla övünüp, ona divan edebiyatı kalıplarına göre yazıımış şiirlerini gösterdi. Fransa'dan yeni dönmüş olan Hamdi Bey'in tepkisi ise kesindi: "Şair olmak, Tezkere-i Şuera'da adları geçen salakların adlarına bir yenisini eklemekten ibarettir".

Bunun üzerine, Ahmet Midhat Efendi, hayatın edebiyata çalışmaktan daha derin bir anlamı olduğunu kavradı ve kendisini büyük bir ansiklopedist ve geniş anlamda "halk eğitimcisi" yapacak olan kaynakları deşmeye başladı (Aktaran Mardin, 2002: 60). Benzer şekilde "küçümseyici" tavra şu alıntıda rastlanmaktadır. Burada, hemen her konuda fikir sahibi olmasını ve her şeyden anlamasını oğluna tavsiye eden; ancak oğlunun torununa tek bir şeyden anlamasını öğütlemesini isteyen, günü bilen bir düşünür olarak onun icaplarını yerine getirirken, bir diğer yükümlülüğünün de halkını geleceğe hazırlamak olduğu inancıyla davranan bir Ahmet Mithat portresi karşımıza çıkmaktadır (Aktaran Dayanç, 2012: 838).

Bu eleştirileri, "Tanzimat'tan bu yana Türkiye'de Batı düşüncesini, felsefesini ve özellikle üzerinde çok durulan Aydınlanma'yı benimseme ve özümleme çabaları da aslına sadık olmayan bir kopyadan ileriye geçemediği ve öncesi ve sonrası olmayan havada, soyut ve bulanık bir düşünce yığını olarak kaldığı ve siyasal iktidarın resmi ideolojisinin gerekçesi ve çoğunlukla da bir baskı aracı olarak iş gördüğŭ” yönündeki saptama ile beraber değerlendirdiğimizde oldukça anlamlı hale gelmektedir. 
görülen pozitivizm, onun devamı mahiyetinde olan bilimcilik ve ansiklopedizm Türk düşünce hayatı içinde 1980'li yılların sonlarına, internet çağına kadar varlığını hep canlı bir biçimde sürdürür. Türkiye'nin batıılaşma serüveni içinde hep arzulu bir biçimde yaklaşılan bilim ve bunu temsil ettiği varsayılan ansiklopedi olgusu, anılan tarihlere kadar içinde okur yazar olan hemen her evin belirgin kültürel aksesuarları arasında sürekli kendisine yer bulmuş ve seksenli yıllarda gazetelerin cazip promosyon faaliyetleri arasında yer almıştır (Uğurlu ve Balık, 2009: 2336).

Abdullah Cevdet'in ilk zamanlar Osmanlı dergisinde sonradan da kendi çıkardığı İçtihad'da laikleşme politikasının temellerini attığı ve özellikle İçtihad'daki fikirleriyle Atatürk devrimlerinin öncülüğünü yaptığı varsayılan bir çok düşünceye değindiğinden söz edilir (Aktaran Uğurlu ve Balık, 2009: 2315). Bilimcilik düşüncesini ansiklopedist diye nitelendiren aydınlardan alan Abdullah Cevdet'in bu düşüncesi II. Meşrutiyet ve Cumhuriyet ideolojileri üzerinde de etkili olmuştur (Uğurlu ve Balık, 2009: 2315).

\section{Sonuç}

Ansiklopedi, diğer bütün bilgi kaynakları gibi içinden çıktıkları toplumların siyasi, ekonomik ve toplumsal formasyonlarını birebir yansıtırlar, böylelikle de onların tarihsel süreçlerini incelerken dönemlere ilişkin anlamlı bilgilere ulaşmak mümkün hale gelir. Bu nedenle de ansiklopediyi, "bilgiyi sistemli bir halde sunmak, bilgiye kolay ulaşmak ve güncel bilgileri sağlama amacında olan bir başvuru kaynağı gibi görmek ya da tanımlamak" oldukça sığ bir yaklaşımda bulunmak olacaktır. Bilginin kontrolü bağlamında ansiklopediye bakıldığında daha anlamlı bir tablo ortaya çıkmaktadır. Yunan sitelerinde görülen ilk örneklerinde ve hatta Ortaçağ dönemindeki örneklerinde her ne kadar "modern" ansiklopedilere benzememesi nedeniyle örtülü olarak ilkel bulunsa da hatta bir bakıma kabul görmese de o dönemlerde modern çağda olduğundan daha fazla insan bilgisini artırma yoluyla özgürleşmeci bir mantaliteye sahip olduğu düşünülmektedir. Yine modern ansiklopedilerin ise, sistematik olma görüntüsü altında bilginin bütünselliğinin parçalandığını bölerek bir anlamda kasıtlı bir biçimde ayrıştırdığını öte yandan da birbirinden farklı neden sonuç ilişkileri bulunan, farklı koşulların ürünü olan şeyleri ise birbiriyle eşleştirerek aynılaştırdığını ya da yansızlık ilüzyonu kurarak aslında kişisel yorum ve değerlendirmeleri genel doğrularmış gibi gösterdiğini kısaca bilginin özgürleştirildiği belirtilen dönemde daha dar bir alanın içerisine hapsedildiği düşüncesiyle bireylerin eleştirel düşünümselliklerini azaltma yönünde işlev gördüğüne inanılmaktadır. Şu da göz ardı edilmemesi gereken bir noktadır ki, ansiklopedi ansiklopedizm halinde, yani Ortaçağın kırılış anında gerçekten bir aydınlatma düşüncesi ile oluşsa da ilerleyen dönemde bu seyrin devam ettiğine inanmak güçtür. En azından şu da belirtilmelidir: Ansiklopedizmin oluştuğu topraklarda yani orijinal halinde sağlıklı ve anlamlı bir sürece işaret etse de, ithalinde zihniyet transferi şeklinde değil de biçim transferi olarak algılandığı için bilgi ya da kültür sembolü olmaktan ziyade içeriği boşaltılmış bir aksesuara dönüşmüştür. 


\section{Kaynakça}

Alfabetik Okul Ansiklopedisi (1990). Ansiklopedi Maddesi. 2, Görsel Yayınlar Ansiklopedik Neşriyat Ticaret ve Sanayi A.Ş.

Ana Britannica Genel Kültür Ansiklopedisi (1993). “Ansiklopedi Maddesi”, Cilt 2, Ana Yayıncılık. A.Ş.

Burke, Peter ( 2001). Bilginin Toplumsal Tarihi, İstanbul: Tarih Vakfı Yurt Yayınları.

Büyük Larousse Ansiklopedisi (1995). “Ansiklopedi Maddesi”, 2. Cilt, İstanbul: Milliyet Gazetecilik A.Ş.

Cumhuriyet Ansiklopedisi (?). "Ansiklopedi Maddesi”, İkinci Cilt, İstanbul: Arkın Kitabevi.

Çetinkaya, Bayram Ali (2008). "Meşrutiyet Dönemi ( 1876-1909) Aydın ve Devlet Adamının /Bürokratının Kimlik Yapısı, C. Ü. İlahiyat Fakültesi Dergisi, 7(2): 75-120.

Dayanç, Muharrem (2012). “Ahmet Midhat Efendi ve Üss-i İnkılap Üzerine”, Turkish Studies, Winter: 7(1): 837-847.

Dictionnaire Larousse (1994). “Ansiklopedi Maddesi,”Cilt 1, Milliyet Gazetecilik A.Ş.

Diderot ve D’Alembert (2000). Ansiklopedi ya da Bilimler, Sanatlar ve Zanaatlar Açıklamalı Sözlüğü, Çev., Selahattin Hilav 2. baskı, İstanbul: YKY.

Gelişim Hachette (1993). Ansiklopedi Maddesi, 1, Interpres Basın ve Yayıncılık A.Ş.

Genç, Ernur (2007). “Tanzimat’tan Cumhuriyet’e Kimlik, Misyon ve Vizyonu Bağlamında Türk Aydını, Akademik İncelemeler, 2(1): 133- 174.

Genç Larousse Ansiklopedisi (1993). Ansiklopedi Maddesi, Cilt 1, Gerçek Yayıncılık

Görsel Büyük Genel Kültür Ansiklopedisi (1987). 2, Görsel Yayınlar.

Grand Master ( 1992). Ansiklopedi Maddesi, 1, Milliyet.

Hilav, Selahattin (2000). "Ansiklopedi ve Aydınlanma Felsefesi", Ansiklopedi ya da Bilimler, Sanatlar ve Zanaatlar Açıklamalı Sözlüğü (Seçilmiş Maddeler), Diderot ve D’Alembert, 2. baskı, İstanbul: YKY.

İnönü Ansiklopedisi (1949). Ansiklopedi Maddesi, Cilt III, Ankara, Milli Eğitim Basımevi.

Kafadar, Osman (1997). Türk Eğitim Düşüncesinde Batılılaşma, Ankara: Vadi Yayınları.

Karamanoğlu, Osman Korkmaz (2007). Ansiklopedik "Izmler” Sözlüğü, Anahtar Kitaplar Yayınevi.

Korkmaz, Ali ve İbrahim E. Bilici (2011). "Şerif Mardin'in Sosyal Değişim ve Kültürel Tartışmalarında Modernleşme, İletişim ve Dil Bağlantısı”, Erciyes Üniversitesi Sosyal Bilimler Enstitüsü Dergisi, 31(2): 31-55.

Koyuncu, Ahmet Ayhan (2013). "Özne ve Hakikat Bağlamında Modern ve Postmodern Epistemolojinin Eleştirisi: Vasat'ı Yakalama Üzerine Bir Deneme”, II. Türkiye Lisansüstü Çalışmalar Kongresi Bildiriler Kitabı-I, 6- 8 Mayıs, 
Bursa, Star Matbaacılık, ss. 7-19.

Mardin, Şerif (2002). Türk Modernleşmesi. Makaleler 4. Mümtaz’er Türköne / Tuncay Önder. 11. Baskı, İstanbul, İletişim.

Mardin, Şerif (2012). Jön Türklerin Siyasi Fikirleri, 18. baskı, İstanbul, İletişim.

Meydan Larousse (1992). Ansiklopedi Maddesi, Sabah.

Oskay, Ünsal (2008). Yıkanmak İstemeyen Çocuklar Olalım. İstanbul: YKY Cogito.

Öztürk, Nurettin (2001). “Aydınlanma Hareketi ve Yeni Türk Edebiyatı”, Pamukkale Üniversitesi Eğitim Fakültesi Dergisi, Sayı: 9: 45-58.

Pamuk, Orhan (1994). Sessiz Ev. 11. Baskı, İstanbul: İletişim.

Temel Britannica ( 1992), Ansiklopedi Maddesi, Cilt 1, Hürriyet Ofset.

Uğurlu, Seyit Battal ve Macit Balık (2009), "Sessiz Ev’in Hayaleti: Güdük Bir Aydınlanma

Projesi", Turkish Studies. Fall, 4(8): 2307-2339.

Yeni Rehber Ansiklopedisi (1993), Ansiklopedi Maddesi, 2, Ihlas Gazetecilik Holding A.Ş.

Yiğitbaş, Maksut (1998), "Illk Romantiğimiz: Ahmet Midhat Efendi”, Atatürk Üniversitesi Türkiyat Araştırmaları Enstitüsü Dergisi. Sayı: 10: 123-128. 